ROCZNIKI PEDAGOGICZNE

Tom 12(48), numer $4-2020$

DOI: https://doi.org/10.18290/rped20124-7

URSZULA GRUCA-MIĄSIK

\title{
INNOVATION IN INITIAL DIAGNOSIS STIMULATING THE DEVELOPMENT OF MORAL REASONING IN PEDAGOGICAL COUNSELING
}

\section{INTRODUCTION}

Morality is an important, but also one of the hardest to explore due to its subjectivity, distinguishing feature of a personal human life. All research relating to moral life, reveals various aspects that characterize human morality. One of these aspects is the development of moral reasoning, proceeding through subsequent stages and the state of this process in the case of individual units. Moral reasoning is gradual, meaning less or greater ability, availability to order moral judgments. It can be described as a process of development because the human knowledge and experience, the identity through which we look at the reality of moral choices grow with age.

Development is an appropriate description of this process, as with age the human knowledge, experience, the possibilities of the intellect are increased, the network of concepts, the a priori identity through which we look at the reality of moral choices becomes richer.

It is important to add also a remark about external, environmental determinants to the strong thesis about the significant influence of unconscious factors on the development of moral reasoning. The moral reasoning of a particular individual is a synthesis of personal, internal and other factors that determine its environmental determinant e.g. family, school or peers.

The obligation to shape even more effective moral education is associated with the possibility of a real impact on the moral identity of each person.

Dr habil. prof. UR URSZULA GRUCA-MiĄSIK - Faculty of Pedagogy, University of Rzeszow; address for corresspondence: ul. ks. J. Jałowego 24, 35-010 Rzeszów; e-mail: grucamiasik@ ur.edu.pl; ORCID: https://orcid.org/0000-0002-3797-8489. 
This is not easy during contemporary reality that is quickly changing. This poses serious challenges for every human being especially when it comes to moral judgments. In this context, a man, struggling with increasing ambivalence, particularly in the area of moral dilemmas, needs moral education. One of its areas may be the innovation in initial diagnosis. It opens the space for stimulation of moral reasoning development process of an individual who has own specific experiences and life history. In the article I refer to the possibility of stimulating moral reasoning at the level of initial diagnosis by a school pedagogue using the method of a diagnostic survey and survey technique and a research tool of my own design, which was verified during ten years of professional work as a teacher in high school, among the first grade youth.

When formulating the thesis about the significant influence of unconscious factors on the development of moral reasoning, we need to mention also environmental determinants. The moral reasoning of a particular individual is a synthesis of personal and internal factors as well as environment, especially family, school or peer groups (Gruca-Miąsik, 2018, p. 1720). The obligation to shape effective moral education is associated with the possibility of a real impact on the moral identity of each person. This is not easy during contemporary reality that is quickly changing. Serious challenges are posed for every human being especially when it comes to moral judgments. In this context, a man, struggling with increasing ambivalence, particularly in the area of moral dilemmas, needs moral education. One of its areas may be the initial diagnosis, opening the space for stimulation.

"For a spiritual and intellectual balance, to overcome stressful situations, people need a new weapon that he can find in themselves, although sometimes they are not aware of it as it has not been developed" (King, Schneider, p. 204). A reliable diagnosis of a student is the basis of all practical activities in pedagogy, sets the direction of a teacher's purposeful and conscious work and is fundamental to the effectiveness of pedagogical interactions. It is applicable in direct education, corrective, compensatory, therapeutic, preventive and rehabilitation activities as well as in pedagogical counseling, consultancy, expert opinions, organizational and animation activities (Jarosz and Wysocka, 2006, p. 23). 


\section{SELECTED LITERATURE REVIEW AND QUESTIONS REQUIRING FURTHER RESEARCH}

Most of research show us the results of investigations how individuals reason about moral problems but they do not show how to improve it working with teenagers. One of its elements is solving moral dilemmas but first we need to create the solid basis for it in a form of the network of moral concepts and this requires further research.

We can take into consideration many authors who were interested in moral reasoning (Armon, 1998) but it is impossible, in this article, to discuss them all. For example, the results of James Weber and Dawn R. Elm (2018, p. 415-458) show that the Millennials in this study exhibit differences in moral reasoning based on gender, intelligence, work experience, and academic major, however not necessarily in an expected manner. Differences in moral reasoning were found when the context or "story pull" of the ethical dilemmas presented is considered. In addition, a comparison to other studies shows that business student Millennials tend to reason at lower levels of cognitive moral reasoning than non-business college students, as well as college students in the 1960s-1970s (Baby Boomers) and in the 1980s1990s (Generation Xers).

We can find in the literature the reflection that an effective training method that improves employees' ability to make ethical decision is needed. The study by W. Huang and J.C. Ho (Huang, Ho, 2018, p. 583-596), based on social cognitive theory, proposes that employing games in an ethics training program can help improve moral reasoning through actively engaging learners. These findings suggest that a game-based ethics training program could effectively develop moral reasoning, and shape moral views better than a non-game-based training program.

In their work, Natalia M. Mintchik, Timothy A. Farmer investigated associations between moral reasoning and epistemological beliefs in an accounting context among senior accounting students from a public university in Midwestern U.S. (Mintchik, Farmer, 2009, p. 259-275). No significant correlations were found between accounting students' principled reasoning about Thorne's ethical dilemmas and their beliefs about knowledge measured by administering Schommer epistemological questionnaire. The results suggest that reflective thinking and moral reasoning represent separate dimensions of cognitive process which develop at a different pace. Thus, a stand-alone course of ethics in accounting education is warranted since 
higher moral reasoning does not automatically follow from extended technical education and improved critical thinking skills.

Another study was the first to examine in a single model whether callous, uncaring, and unemotional traits are directly related to the perpetration of bullying and to harm-effect moral reasoning in bullying among children as well as whether these three $\mathrm{CU}$ traits are indirectly related to bullying mediated by harm-effect moral reasoning (Thornberg and Jungert, 2017, p. 559-575). The study was conducted in 13 schools in Sweden using structural equation modeling to test the hypotheses. Results when all three sub-constructs of CU traits were included in a single model, greater callousness and uncaring were directly associated with greater bullying. In contrast, greater harm-effect moral reasoning was associated with less bullying. Moreover, greater callousness and unemotional were indirectly associated with greater bullying through the reduced use of harm-effect moral reasoning. The authors' findings demonstrate that all three CU traits are important to address, although their associations with bullying took some different paths.

Reflective thinking is very important when working with teenagers especially in the direction of moral reasoning. But first it is important to start with a simple initial diagnosis which will be stimulating the process of development of moral reasoning. By asking special questions we help them to wonder how they think and what kind of problems they have. It seems to be important that first we need to create the solid basis for it in a form of the network of moral concepts and this requires further research.

\section{THE AIM}

The aim of this article is to show the innovation and value of self-constructed research tool- questionnaire for initial diagnosis which can stimulate the process of developing moral reasoning of teenagers in the work of the school pedagogue in pedagogical counseling on a specific example based on the perspective of thirty years work experience as a pedagogue and many personal scientific investigations of a theoretical and research nature. The author of this article concludes that even the diagnostic level can stimulate the person, be encouraging and liberating. 


\section{The methodology, material research and results}

The dictionary of foreign words explains the word stimulate as "stimulate to act, excite, encourage, enhance life processes of the body, act as a stimulus, motive," but also "french-stimuler, from Latin-stimulo," "drive," from stimulus "a sharpened stick to drive the oxen" (Tokarski, 1997, p. 1047). The last understanding of this concept is undoubtedly not of a pedagogical nature, while the concepts defined by the term: stimulation to action, encouragement, stimulus are keywords in the work of a pedagogue. By linking stimulation "with the process of improvement the development, stimulation should then be understood as creating a situation and encouraging actions leading to self-realization" (Kielar-Turska, 1992, p. 20). It is about stimulating life and cognitive processes, improving and reforming competences by developing emotional intelligence, psychological resilience leading to strengthening of personal development.

"Research shows that social and emotional skills can be more important for achieving success in life than the high IQ measured by standard tests of verbal and nonverbal cognitive intelligence" (Shapiro, 1999, p. 20) and therefore the task of a pedagogue is to stimulate children and young people towards acquiring the ability to cooperate and communicate, empathy, solving problems and conflicts in a peaceful way in correlation with reparation. It is also about showing how to deal with emotions, teaching constructive behavior in difficult situations, developing a sense of "self," effectiveness, self-awareness, sense of life and its purpose, building optimism, aspirations, internal motivation for development, self-healing, self-actualization, participation in responsible activities.

Altruism, wisdom, harmony that gives strength, optimism, internal warmth, activity and expressiveness related to self-realization and quality of life are associated with stimulating the emotional and social area. An important issue is to mind the effect of coherence, because it strengthens in children and adolescents a sense of sensibility of the taken actions. Stimulation of children and youth's largest possible number of areas in functioning as well as adequate, thoughtful, attractive in their form activities supporting development, and also in-depth diagnostic tests are the basic tasks of the pedagogue. Being a professional teacher is a great challenge especially for a young pedagogue, taking into account the fact that each school has its specificity due to the local environment in which it is located, the scope of the needs of individual students that require first satisfaction, the specific expectations of the school's management and authorities, as well as stu- 
dents,' teachers' and parents' expectations, which are not always consistent. In this respect, it seems obvious that this work requires a lot of knowledge, skills, creativity and flexibility as well as practical experience which can only be provided by years of work. Continuous improvement of the qualifications, recognition of the latest trends and ways of working with children and young people, high substantive knowledge, building own work skills and broadening horizons are the basic tasks of the pedagogue. Additionally, and perhaps first and foremost, the pedagogue's professionalism and personality traits should be emphasized. Among them it is important to recognize responsibility, justice, empathy, optimism and "infecting with joy and a smile," conciliation, a high level of moral reasoning and ethical attitudes. An important aspect of the pedagogue's work is to prevent school failures and create a help system in learning, which in practice takes place through didacticcompensatory or corrective-compensatory work, creating a help system in learning by organizing cooperation between students having school failures and peers achieving higher educational results. The ally in this area is psychological and pedagogical counseling which diagnoses many aspects. Thanks to the issued opinion on the student's intellectual abilities or possible disorders it helps to direct the work at school with a given student in cooperation with teachers and parents.

Due to the fact that many of school failures are related to the students' family situation, an important work direction is to cooperate with their family environment. Reliable information for parents about the situation of the child is the responsibility of the educator, as well as psychoeducation, counseling, and support in education, situations of threat to the child's safety due to improper functioning of the family system, and providing proper therapy. The environmental activity of the pedagogue is connected with the family, because it is linked to living conditions and social situation of pupils. It also has a wider range, because the pedagogue cooperates with many institutions, organizations, associations, teams etc. It should be based on cooperation with universities, centers of teachers' improvement and the police, sometimes courts and curators. Children's work in volunteerism, piloted by a pedagogue is well-seen and highly useful. This will be more difficult without the cooperation with local environment. A very important direction of the pedagogue's activities is to take the role of a coordinator and mediator in situations related to education and upbringing (Gruca-Miąsik, 2011, p. 48-80), which are: recognizing the threat situations resulting from developmental problems, personality, teacher-student, parent-student and 
student-student relationships. The pedagogue mustprovide meditations on controversial issues and conflicts, but also coordinating preventive activities and organizing therapies, fending skills, interests, creativity and dreams of pupils, setting together with students norms, principles and boundaries that guide young people at school and personal their life, conducting moral education by solving moral dilemmas that stimulate the development of moral reasoning and ethical attitudes (Gruca-Miąsik, 2015, p. 359-377). It is also crucial to coordinate education in the field of social skills so important in contemporary professional and social life.

As the first stage of the pedagogue's work, the diagnosis becomes a signpost when undertaking educational, stimulating, compensatory, corrective, therapeutic, compensatory and preventive actions. From the perspective of thirty years work experience as a pedagogue and many personal scientific investigations of a theoretical and research nature, the author of this article concludes that even the diagnostic level can stimulate the person, be encouraging and liberating. It can stimulate awareness of both the pedagogue and the pupils. In this publication, I present my own diagnostic questionnaire, developed ten years ago for the first grade high school teenagers, in which I have the opportunity to improve my pedagogue's work technique. It is annually modified depending on the results of the analysis of the enrollment documents and adequately to the needs of the school. The results of the diagnosis allow to develop a work plan for the following three years in the main areas of the pedagogue's work and allow to set directions for support and assistance in individual cases.

It is assumed that the initial diagnosis enables better, more creative and more effective planning of the pedagogue's work.

I present below a self-constructed research tool-questionnaire for initial diagnosis which can stimulate the process of developing moral reasoning already when wondering and answering the questions.

\section{QUESTIONNAIRE FOR THE FIRST GRADE STUDENTS (year.......)}

Dear students!

You are students of the High School. I am kindly asking you to fill in the questionnaire below, which will allow me to get to know you better and help you more effectively. Answer the questions with the " $\mathrm{X}$ " in the shaded fields, circle them or fill in. 
SURNAME AND NAME

1. Do you like to perform In public?

Yes No

2. Were you under psychological and pedagogical help at school?

Yes No

3. Have you smoked cigarettes?

Yes No

4. Have you drunk an alcohol?

Yes No

5. Have you tried designer drugs?

Yes No

6. Is drinking alcohol a problem in your home?

Yes No

7. Have you experienced violence?

Yes No

8. How did you find out about our school: (you can choose as many as you like)

A From older friends

B From teachers in your former school

C From the teachers of our school recruiting at your junior high school

D From the Internet

E From the press

F From the radio

$\mathrm{G}$ From the television

H From another Source, which one?

9. You assess the financial situation of the family as:

Very good Good Sufficient Poor

10. Do you have an opinion or advisory judgment from the pedagogical institution?

YES, NO 
11. Are you under the supervision of a probation officer? YES, NO

12. Is one of your parents abroad?

Father: YES, NO Mother: YES, NO

13. What type of family do you live in: full, reconstructed (remarriage), foster family, incomplete (single mother, single father), the parent has passed away?

14. During school year you live: at home, in boarding school, rent a room, with relatives, with family's friends, in a facility, other.

15. Do you use social assistance: YES, NO

16. Who do you live with:

a) Father

b) Mother

c) Siblings (how many)

d) Grandmother

e) Grandfather

f) others (who?)

17. What time do you get up, how many kilometres do you have to school?

18. Health: do you suffer from any diseases?

19. In your opinion, which school subjects are you good at?

20. What are you interested in?

21. What is your passion?

22. What will you do in 10 years' time and who will you be?

23. What rewards do parents use to praise you?

24. What are the penalties your parents apply to you?

25. Complete the sentences:

My dream is 
I'm afraid of

I would like to

26. Which of your Leeds are not met? (specify)

a) At school

b) At home

27. Specify which extra-curricular activities and circles of interest you would like to attend

28. What skills do you have:

a) I sing

b) I play the instrument (which one?)

c) I recite

d) I write poems, prose

e) I do Martian arts (which ones?)

f) Sport (which one?)

g) Others (specify)

29. Do you have any distinctions, diplomas or successes? Please share your joy, where and when it was, for what, etc. Even the smallest ones are relevant to the whole

30. How do you spend your free time?

31. Who in the class has leadership skills? (choose 1 person)

32. Please share your suggestions and insights about the school environment, could you like to change something?

Thank you very much for your trust — Pedagogue Urszula Gruca-Miąsik

The questionnaire is not anonymous, because we help specific individuals and groups. It consists of thirty-two questions and was published together with its analysis in collective work (Gruca-Miąsik, 2016, p. 258-260). The initial nine questions are categorized. These are settlement questions (7) and questions of choice (2). The next six ones are settlement questions and the remaining ones are: open, completion and selection ones. The respondents are asked if they like to appear in public, in order to select individuals who are ready to undertake activities requiring social exposure, as well as people 
who need help. The question about psychological and pedagogical help makes it easier for the pedagogue to proceed and provide it. It is important to ask young people about taking risky behaviors such as smoking, drinking alcohol or taking drugs, because even if not everyone wants provide true answers, it will be easier to start work and take adequate activities with the ones who do.

The important information is parents' alcohol abuse and also whether they have experienced violence (in the individual contact the source of this violence is revealed). Even if it may seem surprising to some, young people often speak honestly. This allows people who report those problems to be offered immediate assistance, support, therapy and strengthening their potential. The fairly common struggle of modern schools for every student-candidate, at the time of demographic decline, dictated the multiple-choice question about a source of information about the school, in order to be able to recruit more consciously in the following year. The financial situation of the youth, subjectively perceived, indicates the level of satisfaction of material needs and the consequences resulting from it (the possibility of using culture, participation in school trips, tutoring if necessary, etc.), and shows who needs urgent help in this regard. The opinion or advisory judgment is an important document, very helpful to young people and teachers in organizing the didactic process and supporting the student individually. Since some young people are afraid to submit this document for various reasons, the question in the survey solves this problem directly, and it helps the pedagogue to start quickly a stimulative-therapeutic-supportive process, as it is in the case of a question about a probation officer. The problem of Euro-orphanhood is a serious challenge for Polish society and the youth deal with it differently, sometimes this situation leads to serious emotional disturbances, sometimes to aggressive behavior. Knowledge about the child's situation in this aspect is therefore absolutely necessary in order to launch a whole range of supporting activities. Family structure, especially when we deal with lonely parenthood, orphanhood, foster family (Gruca-Miąsik, 2012, p. 49-70), limited parental rights or their deprivation, is a significant reason and requirement for multi-directional pedagogy, as is the case when a student lives outside the family home. Information about the use of social assistance verifies the question about the financial situation, and at the same time indicates the need to contact a social worker. The question about the family system allows the pedagogue to become familiar with the family situation of the pupils in question. Many students commute to school, sometimes as far 
as 50 kilometers. A lot of them belong to the dispensary group, suffering from various kinds of illness. The knowledge about this allow the pedagogue, a form teacher and also other teachers to surround them with care activities. The diagnostic-stimulating aspect is particularly evident in building self-awareness in pupils through reflection on which subjects they are good at, which ones they are interested in, what they are passionate about, who they would like to be and what they will do in 10 years' time. Thanks to such questions, the pupils have a chance to look inside themselves, to project the future, to set closer and further goals with the pedagogue.

Feedback from students provides clear information that for the first time, they had the opportunity for such reflection. Penalties and rewards used in the family show parenting skills and direction of the pedagogue as part of the so-called pedagogization of parents. A good practice is a workshop for parents within the School for Parents and Educators implemented in high school. The next question, about dreams, fears, expectations, having a projection character allows to reveal often hidden, unverified states and situations. When they are already written down, tamed, become good stimulus for action. Awareness of young people's needs is at a low level, hence this kind of question opens the way for discussion during classes with the pedagogue. The students have many interesting proposals for activities outside of the classroom and the school's task is to respond to the needs of young people and verify own ideas which are sometimes unattractive from the point of view of young people. Students who come to school have many skills but there is not always the opportunity to present them. They can be encouraged to use their talents at school. Obtaining such information by the pedagogue at the end of the pupil's school education, as well as acquiring knowledge about their successes at previous stages of education would be practically pointless. Many educators concentrate only on pupils' school situation, whereas knowledge about the ways of spending free time is an important variable affecting their achievements. It also gives the opportunity to conduct interesting preventive activities with the youth. A short sociometric study allows to find a natural leader, it is repeated after three months and supplemented with the criterion of sympathy and knowledge, followed by pedagogical activities supporting those students who are not popular. The results of this work are verified again at the end of the school year. In the last question, opinions about the school environment and suggestions for possible changes are collected. Each questionnaire is analyzed in detail by the pedagogue, a plan of different interactions is prepared for every student 
depending on the needs. Then, the pedagogue prepares a collective sheet for a class and presents it to the class tutors and on the educational team, where the directions of interactions, prevention, care and educational work are discussed and agreed upon.

\section{CONCLUSIONS}

Modern times bring many stressful situations for young people and pose serious moral dilemmas, which have to be faced and resolved. Due to the fact that family environments in which they grow are not always conducive to the moral development of a young person, pedagogues become hope, guides, moderators of the discussion and support in solving important moral dilemmas. They help the pupils to develop his/her own abilities, build a spiritual and intellectual balance, overcome stress and many other problems thanks to the new skills. An important role in these activities plays initial diagnosis, enabling young students to accompany the process of developing moral reasoning. Having at least knowledge about their life experiences, moral competences, it is easier to shape the pedagogue's way of work stimulating their development of moral reasoning. Preparing graduates of pedagogy for work as school pedagogues, unfortunately often has a very theoretical character. This makes it difficult to start the practical fulfillment of duties in this position. Young pedagogues therefore improve their skills and gain experience during every day work, through trial and error method on the "living" material-their students.

\section{REFERENCES}

Armon, C. (1998). Adult moral development, experience and education. Journal of Moral Education, 3, 345-370.

GrUCA-Miąsik, U. (2011). Negocjacje i mediacje - w kregu pomocy, wychowania i prawa [Negotiations and mediations - in the circle of help, education and law]. Rzeszów: Wydawnictwo UR.

GruCA-Miąsik, U. (2012). Moral Dimension of Functioning of Foster Families Viewed From the Systemic Perspective (2001-2011). Rzeszów: Wydawnictwo UR.

GRUCA-MiąsiK, U. (2015). Rozumowanie moralne młodzieży. Wybrane obszary i konteksty [Moral reasoning of young people. Selected areas and contexts]. Rzeszów: Wydawnictwo UR.

GRUCA-MiĄSIK, U. (2016). Diagnostyczno-stymulująca działalność pedagoga szkolnego w sytuacji opiekuńczo-wychowawczej [Diagnostic-stimulating activity of a school counselor in a care and educational situation]. W: U. GRUCA-MIĄSIK (ed.), Opieka jako kategoria wychowawcza. Metody i formy stymulacji dzieci i młodzieży $w$ rodzinie i środowisku lokalnym [Care as an 
educational category. Methods and forms of stimulation children and youth in the family and local environment] (p. 249-260). Rzeszów: Wydawnictwo UR.

GRUCA-MiĄSIK, U. (2018). Rozumowanie moralne - osoba, rozwój wychowanie [Moral reasoning - a person, development, upbringing]. Rzeszów: Wydawnictwo UR.

HuANG, W., Ho, J.C. (2018). Improving moral reasoning among college students: a game-based learning approach. Interactive Learning Environments, 26(5), 583-596.

Jarosz, E., Wysocka, E. (2006). Diagnoza psychopedagogiczna. Podstawowe problemy i rozwiazania [Psychopedagogical diagnosis. Basic problems and solutions]. Warsaw: Żak.

KIELAR-TuRsKa, M. (1992). Jak pomagać dziecku w poznawaniu świata [How to help your child in learning about the world]. Warsaw: WSiP.

KING, A., SCHNEIDER, B. (1999). Pierwsza rewolucja globalna. Jak przetrwać? [The First Global Revolution. How to survive?]. Warsaw: Polskie Towarzystwo Współpracy z Klubem Rzymskim.

MinTCHIK, N.M., FARMER, T.A. (2009). Associations Between Epistemological Beliefs and Moral Reasoning: Evidence from Accounting. Journal of Business Ethics, 84, 259-275.

SHAPIRO, L.E. (1999). Jak wychowywać dziecko o wysokim EQ? [How to raise a child with a high EQ?]. Warsaw: Prószyński i S-ka.

Thornberg, R., Jungert, T. (2017). Callous-Unemotional Traits, Harm-Effect Moral Reasoning, and Bullying Among Swedish Children. Child and Youth Care Forum, 46(4), 559-575.

TOKARSKI, J. (1997). Stownik wyrazów obcych [Dictionary of foreign words]. Warsaw: PWN.

Weber, J., Elm, D.R. (2018). Exploring and Comparing Cognitive Moral Reasoning of Millennials and Across Multiple Generations. Business and Society Review, 123(3), 415-458.

\section{INNOVATION IN INITIAL DIAGNOSIS STIMULATING THE DEVELOPMENT OF MORAL REASONING IN PEDAGOGICAL COUNSELING}

\section{SUMMARY}

Triggering the developmental potential of students, also in the sphere of morality, is one of the main tasks of education. Performing didactic, educational, protective and preventive functions, in addition to teachers the school employs pedagogues to carry out these functions. Undoubtedly, their important tasks include diagnosis, which is confirmed by the law and regulations governing their work. It is expected that the school, in addition to the passing knowledge, will develop in young people the desired level of axiological competence, their talents and predispositions, different types of skills, especially of a social nature, shape creativity, sensitivity or expected moral attitudes. The changes taking place in the modern world, including Poland, have caused, on many levels and also in education, a crisis that results in many individuals being lost, not believing in their own abilities, but also in selfishness. The aim of this article is to show the innovation and value of self-constructed research tool-questionnaire for initial diagnosis which can stimulate the process of developing moral reasoning of teenagers in the work of the school pedagogue in pedagogical counseling on a specific example based on the perspective of thirty years work experience as a pedagogue and many personal scientific investigations of a theoretical and research nature. The author of this article concludes that even the diagnostic level can stimulate the person, be encouraging and liberating. The paper argues that in care and educational situation, which is the domain of the pedagogue's activity, the diagnostic work, especially the stimulation, plays the key role. It allows not only to diagnose, but also gives the opportunity to 
stimulate the researcher's self-reflection, showing the perspectives and opportunities that may not have been previously noticed. The method of the diagnostic survey and the survey technique were used. initial diagnosis, enabling young students to accompany the process of developing moral reasoning. Having at least knowledge about their life experiences, moral competences, it is easier to shape the pedagogue's way of work stimulating their development of moral reasoning. Preparing graduates of pedagogy for work as school pedagogues, unfortunately often has a very theoretical character. This makes it difficult to start the practical fulfillment of duties in this position. Young pedagogues therefore improve their skills and gain experience during every day work, through trial and error method on the "living" material-their students.

Keywords: innovation; morality; moral reasoning; upbringing; development; school counselor; diagnosis; diagnosing; stimulation; teenagers; counseling.

\section{INNOWACJE W DIAGNOZIE WSTĘPNEJ STYMULUJĄCE ROZWÓJ ROZUMOWANIA MORALNEGO W PORADNICTWIE PEDAGOGICZNYM}

\section{STRESZCZENIE}

Wyzwalanie potencjału rozwojowego uczniów, także w sferze moralności, jest jednym z głównych zadań edukacji. Myślenie refleksyjne jest bardzo ważne w pracy z nastolatkami, szczególnie w kierunku rozumowania moralnego. Ważniejsze jest jednak, aby zacząć od diagnozy, która oprócz niezbędnych informacji o dziecku będzie, już na tym wstępnym etapie, stymulować proces rozwoju rozumowania moralnego. Zadając specjalne pytania, pomagamy pobudzić refleksję u dziecka i dowiadujemy się, jak myśli i jakie ma problemy. Wydaje się, że w pracy pedagogicznej musimy stworzyć solidne podstawy w postaci siatki pojęć moralnych, a to wymaga czasu i pogłębionej diagnozy wstępnej. Pełniąc funkcje dydaktyczne, edukacyjne, opiekuńcze i profilaktyczne, oprócz nauczycieli szkoła zatrudnia pedagogów do wykonywania tych zadań. Ważnym elementem ich pracy jest niewątpliwie stawianie diagnoz, co potwierdzają przepisy wynikające z ustawy i wykonawcze obowiązujące w ich pracy. Oczekuje się, że szkoła, oprócz przekazywanej wiedzy, rozwinie u młodych ludzi pożądany poziom kompetencji aksjologicznych, talenty i predyspozycje, różne rodzaje umiejętności, zwłaszcza o charakterze społecznym kreatywność, wrażliwość i pożądane postawy moralne. Zmiany zachodzące we współczesnym świecie, w tym w Polsce, spowodowały na wielu poziomach, także w edukacji, kryzys moralny, w wyniku którego wiele osób nie potrafi się odnaleźć, nie wierzy we własne możliwości. Większość badań pokazuje, w jaki sposób ludzie rozumieją problemy moralne, ale nie pokazuje, jak udoskonalić pracę z nastolatkami w tym zakresie. Badacze problemu rozumowania moralnego zwracają uwagę na rozwiązywanie dylematów moralnych jako na ważny element w rozwoju młodzieży. Autorzy zainteresowani rozumowaniem moralnym pokazują np. że pokolenie milenialsów wykazuje różnice w rozumowaniu moralnym w zależności od płci, inteligencji, doświadczenia zawodowego i kierunku studiów, jednak niekoniecznie w oczekiwany sposób. Różnice w rozumowaniu moralnym stwierdzono przy rozważaniu kontekstu przedstawionych dylematów etycznych. Ponadto, porównanie $\mathrm{z}$ innymi badaniami pokazuje, że np. pokolenie milenialsów biznesu ma tendencję do myślenia na niższych poziomach rozumowania moralnego niż studenci niebędący przedsiębiorcami, a także w porównaniu ze studentami lat 60. i 70. XX wieku (wyżu demograficznego) oraz lat 80. i 90. XX wieku (Generacja Xers). W literaturze możemy znaleźć refleksję, że potrzebna jest skuteczna metoda szkolenia, która poprawia zdolność pracowników do podejmowania etycznych decyzji, np. program szkolenia w zakresie etyki oparty na grach mógłby skutecznie rozwijać rozumowanie moralne i kształtować poglądy moralne lepiej niż zwykły program 
treningowy. Celem tego artykułu jest ukazanie innowacyjności i wartości w samodzielnie skonstruowanym narzędziu badawczym - kwestionariusz do wstępnej diagnozy, który może stymulować proces rozwijania rozumowania moralnego nastolatków w poradnictwie pedagogicznym. Autorka tego artykułu stawia tezę, że nawet na poziomie diagnozy wstępnej możemy stymulować osobę, zachęcać i wyzwalać efekty. W artykule argumentowano, że w sytuacji opiekuńczo-wychowawczej, która jest domeną działalności pedagoga, kluczową rolę odgrywają wiedza, umiejętności, doświadczenia życiowe, kompetencje moralne, bowiem to one ułatwiają stymulowanie rozwoju rozumowania moralnego młodych ludzi.

Słowa kluczowe: innowacyjność; moralność; rozumowanie moralne; wychowanie; rozwój; pedagog; diagnoza; stymulacja; młodzież; poradnictwo. 